\title{
Urban Wastewater Characteristic and its Management in Urban Areas-A Case Study of Mysore City, Karnataka, India
}

\author{
Shakunthala Bai, Shivanna Srikantaswamy, Doddaiah Shivakumar \\ Department of Studies in Environmental Science, University of Mysore, Manasagangotri, \\ Mysore, India \\ E-mail: srikantas@hotmail.com \\ Received March 27, 2010; revised July 2, 2010; accepted July 15, 2010
}

\begin{abstract}
The rapid growth of the population, the technological and industrial boom has brought enormous problems and degradation of the environment. There is a gradual decline in availability of fresh water to be used for irrigation in India. As a consequence, the use of urban waste water (UWW) for irrigating agricultural lands is on the rise particularly in peri-urban areas of developing countries. Effective collection and treatment of urban wastewater is a critical problem in a developing country like India. A case study was undertaken to assess the characteristic of the urban waste water and its management in Mysore city and its long-term effect on irrigation. The untreated and treated urban waste water was collected during 2008 and analyzed in the laboratory. The suitability of the UWW for irrigation purposes is then evaluated according to the existing water quality standards and the results were compared with Food and Agriculture organization (FAO) irrigation water quality standards. It is evident from the results, that the current situation is not promising especially regarding the Electrical Conductivity, Total Dissolved Solids, Biochemical Oxygen Demand, Chemical Oxygen Demand, Suspended Solids and heavy metal concentrations and also pH of the treated UWW is exceeding the FAO standards. Among the heavy metals, the concentration of Iron and chromium are exceeding the FAO standards.
\end{abstract}

Keywords: Urban Waste Water, Water Quality Appraisal, Quality of Irrigation Water, Heavy Metal

\section{Introduction}

Expansion of urban populations and increased coverage of domestic water supply and sewerage give rise to greater quantities of urban waste water (UWW). On the contrary, providing safe and sufficient drinking water and proper sewerage system remains as the challenging tasks for many developing countries particularly so, in urban areas. With the increasing scarcity of freshwater resources that are available to agriculture, the use of urban wastewater in agriculture has increased, especially in arid and semi-arid countries. The major challenge is to optimize the benefits of wastewater as a resource of both the water and the nutrients it contains, and to minimize the negative impacts of its use on human health. About $80 \%$ of urban waste in India ends up in rivers where it destroys rivers ecosystems and it also makes bodies of water unfit for human use and if this trend continues the rivers could soon become dead rivers.

UWW means domestic waste water, consisting of blackwater-excreta, urine and associated sludge and greywater-kitchen and bathroom wastewater or the mixture of domestic wastewater from commercial establishments and institutions including hospitals with industrial wastewater and run-off rain water [1] (Figure 1). Non point sources include silt from earth-moving activities; storm runoff from roads, home gardens, and industrial sites, infiltration from aquifers contaminated with domestic waste water or industrial chemicals; and automobile emissions. Domestic waste water created by residences, institutions, hospitals and commercial, industrial establishments, storm-water runoff from roads and other paved areas are frequently discharged into sewers. UWW is mainly comprised of water (99.9\%) together with suspended and dissolved organic solids (carbohydrates, lignin, fats, soaps, synthetic detergents, synthetic organic 


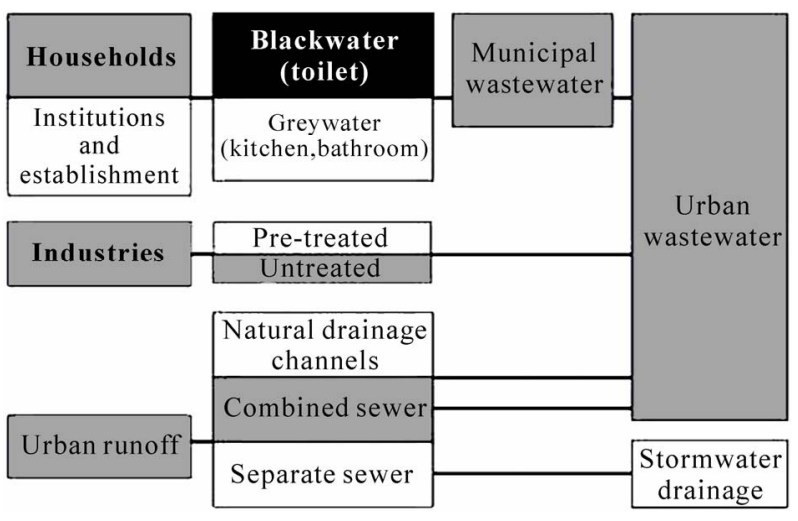

Figure 1. Urban waste water components.

chemicals from the process industries), inorganic solids including metals and also Pathogenic viruses and bacteria.

The fact is that, the UWW may contain toxic substances and discharge of untreated UWW results in contamination of water bodies which is harmful in many ways.

The sources of metal pollution in the UWW system can be classified into three main categories:

1) Domestic source.

2) Small scale industries (connected to the Waste Water Treatment System) and commercial.

\section{3) Urban runoff.}

The other principal sources of metals in UWW are body care products, pharmaceuticals, cleaning products, tanneries, metal plating units, jewellery industry and liquid wastes. Wastewater often contaminated with industrial effluent contains high levels of heavy metals. A large number of the cities/towns either do not have any sewerage system or system is overloaded or defunct. Even where sewers exist, they often leak or overflow, releasing their contents to storm water or other surface drains or percolate in to soil to reach ground water. Thus a bulk of pollution gets retained on land to percolate, leach or get washed-off to streams or groundwater.

All kinds of variations in wastewater use are possible and it is to be expected that different uses will have different impacts on agricultural productivity, the environment, and human health. Appropriate policy decisions and technical interventions are likely to depend on the nature and characteristics of the wastewater and the way in which it is being used. The following three types of wastewater use are the most relevant [1].

Direct use of untreated waste water is the application to land of wastewater directly from a sewerage system or other purpose-built wastewater conveyance system.

Direct use of treated wastewater is the use of treated wastewater where control exists over the conveyance of the wastewater from the point of discharge from a treatment works to a controlled area where it is used for irrigation.
Indirect use of wastewater is the planned application to land of wastewater from a receiving water body.

Irrigation with urban wastewater is a fact of life in and around urban areas in many low-income countries. Not only do the nutrients in the wastewater increase crop yields but also, there are adverse health implications, including bacterial contamination of vegetables and intensive application of pesticides to combat the insect pests that infest these crops [3]. Dietary intake of heavy metals has a substantial risk to the health, which is caused by consuming crops grown by using contaminated UWW [2].

Effective collection and treatment of UWW has become a very challenging task in most of the cities in India. There is a general practice of disposal of UWW into rivers, lakes or on land for irrigation with no treatment at all or with minimum treatment. The present study area Mysore city is having only primary treatment plant, which treats only a part of UWW generated from the city limits and large quantity of untreated UWW is discharged into low lying areas and water bodies located in and around Mysore City. Due to the scarcity of freshwater the untreated and treated UWW is used for irrigation. Hence it is necessary to determine the characteristics of the UWW in context to its utilization to irrigation and to evaluate the performance of the existing treatment plants. In the present study an attempt was made to know the nature and composition of the UWW in Mysore city and the changes in the composition after treatment with the special attention given to the concentration of heavy metal. The aim of the present study was to investigate the concentration of certain metals viz., cadmium, copper, lead, chromium, nickel, iron and zinc. The composition of urban waste water is influenced by the industries located within the area and urban runoff.

\section{Materials and Methods}

The study area Mysore is a unique city having around 12lakh population and was capital of former princely state of Karnataka. It lies between $12^{\circ} 9^{\prime}$ and $11^{\circ} 6^{\prime}$ latitude and $77^{\circ} 7^{\prime}$ longitude and general elevation is little more than 1800 feet above sea level. The climate of the city is moderated throughout the year with temperature during summer ranging from $30^{\circ} \mathrm{C}$ to $34^{\circ} \mathrm{C}$. The rainy season is from May to October. The winter season is from November to February. The source of water for domestic and industrial purpose is mainly from the Cauvery River and ground water.

Mysore is one of the growing cities of Karnataka and it is so largely due to the presence of industrial resources and a well developed communication network. Mysore has a rich and vibrant history and heritage and hence attracts a huge number of tourists. Also, Mysore is now active center for production and industrialization. The 
city has been growing as a counter magnet to Bangalore with large presence of software companies and the population is growing at a faster rate due to the influx of many industrial and commercial activities.

In recent years industrialization has become main cause of city's growth. There is diversity in industrial landscape of Mysore with haphazard distribution. The industrial areas are distributed all over the city and its surroundings with lack of order and regulation in industrial location. A large number of small medium and large scale industries exists in and around the Mysore city, including engineering, chemical, pharmaceutical, food, brewery, distillery, textile, steel and metal smelting.

Mysore has adequate water supply resources due to the proximity of Rivers Cauvery and Kapila. The city has four pumping stations namely Hongally Water Supply Scheme (I \& II stage-8 mgd), Hongally Water Supply Scheme (III stage-12 mgd), Belagola Water Supply Scheme (11.5 mgd), Melapur Water Supply scheme (11 mgd quantity). The topography of the city is such that the entire UWW drains into three valleys viz., northern outfall into Kesare Valley, and other outfalls to the south one into Dalvai tank feeder valley and another to Malalavadi tank valley.

Mysore was one of the earliest cities in India to have underground drainage. In old parts of the city, underground drainage was completed in 1904. The quantity of domestic waste water generated has increased from 80 MLD during 2001 to 128 MLD during 2006-07. The area covered with sewer system is $100 \mathrm{Sq}$. kms and the total length of sewer lines is $740 \mathrm{Kms}$. Only about $57 \%$ of the household are connected to under ground drainage system.

Based on the topography of the city, Mysore city comprises of five drainage districts, namely, A, B, C, D and $\mathrm{E}$ districts respectively, covering different areas (Figure 2). The city has been provided with three waste water treatment plants. For drainage districts A \& D the waste water treatment plant of capacity 60.0 MLD is located at Rayankere, H.D.Kote Road, Mysore. The treatment plant for drainage district B is of capacity 67.65 MLD and it is located at sewage Farm, Vidyaranyapuram, Mysore. The treatment plant for drainage district C is of capacity 30.0 MLD and it is located at Kesare Village, Mysore. The waste water alongwith the waste water from point source and non point sources from different areas of the drainage districts are collected in wet wells and treated in the waste water treatment plants. All the treatment plants have facultative aerated lagoons and sedimentation basins. The process of primary treatment involves simple lagooning and subsequently natural oxidation where by the suspended colloidal particles of the UWW get partly or wholly coagulated and flocculated.

The fifth drainage district $\mathrm{E}$ in the city covers an area around 16 sq.kms. At present, this district does not have a sewerage system. There are several missing links at each district and 30 MLD is discharged as such on land, in low lying areas, which joins water bodies. The missing sewer lines identified in the above mentioned drainage districts are of varying diameters varying from $150 \mathrm{~mm}$ to $900 \mathrm{~mm}$. The total length of missing sewer line identified as of 2002-03 is about 22135 meter. As of 2006-07, the quantity of sewage generated is $125 \mathrm{MLD}$ and 95 MLD is treated. The untreated and treated UWW is largely used for irrigation.

Assessment of UWW characteristics was carried out during 2008, the untreated and treated UWW samples were collected in cleaned 2-L polythene bottles as per the standard methods from the following sampling locations;

Location No. 1: At Kesare Village, Mysore and waste water treatment plant No.1.

Location No. 2: At Sewage Farm, Vidyaranyapuram, Mysore and waste water treatment plant No. 2.

Location No. 3: At Rayankere, H.D.Kote Road, Mysore and waste water treatment treatment plant No. 3 .

The samples were analysed to know the characteristics of physico-chemical parameters of the UWW as follows $\mathrm{pH}$, Electrical Conductivity (EC), Biochemical Oxygen Demand (BOD 5$)$, Chemical Oxygen Demand (COD), Total Dissolve Solids (TDS), Suspended Solids (SS), Sodium Absorption Ratio (SAR), Nitrate $\left(\mathrm{NO}_{3}{ }^{-} \mathrm{N}\right)$, Phosphate $\left(\mathrm{PO}_{4}{ }^{3-}\right)$, Potassium $\left(\mathrm{K}^{+}\right)$.

\section{Results and Discussion}

The samples were analyzed for physic-chemical parameters by using standards methods [4]. The Presence of heavy metals in waste water is one of the main causes of water and soil pollution. The separate samples of untreated and treated UWW were collected for heavy metal analysis and preserved by adding $2 \mathrm{ml}$ of concentrated nitric acid to prevent precipitation of metals and growth of algae. The samples were digested and concentrated 10 times from $100 \mathrm{ml}$ to $10 \mathrm{ml}$ on hot plate. Analysis of heavy metal content of the samples was performed using Inductively Coupled Plasma spectrometry (ICP). The results of physico-chemical parameters and heavy metal are presented in Tables 1 and $\mathbf{2}$ respectively.

The $\mathrm{pH}$ range suitable for the existence of most biological life is quite narrow and critical, and is typically 6-9 [5]. High pH values above 8.5 are often caused by high bicarbonate and carbonate concentrations, known as alkalinity [6]. High carbonates cause calcium and magnesium ions to form insoluble minerals leaving sodium as the dominant ion in solution. Highly alkaline water can intensify sodic soil conditions, which will have implications for agriculture. The $\mathrm{pH}$ analysis of untreated UWW shows a maximum and minimum of 7.96 and 6.63 at location No. 2 during premonsoon and monsoon season 
respectively. The $\mathrm{pH}$ of treated UWW treated UWW show a maximum of 9.11 at location No.1 and minimum of 7.48 at location No. 2 during post monsoon season. Slightly alkaline $\mathrm{pH}$ could be attributed to the detergents present in the UWW and in cases of acidity or alkalinity due to industrial effluent.

It is observed that the $\mathrm{pH}$ of untreated UWW is meeting the FAO irrigation water quality standards. The $\mathrm{pH}$ of treated UWW at treatment plants at location No. 1 \& 2 during monsoon and post monsoon and at location no 3 during all seasons are exceeding the standards which may be attributed to the existing primary treatment process and treatment operational process. Higher $\mathrm{pH}$ over 8.5 may indicate other problems such as high sodium content. The $\mathrm{pH}$ of treated and untreated UWW is shown in Figure 3.

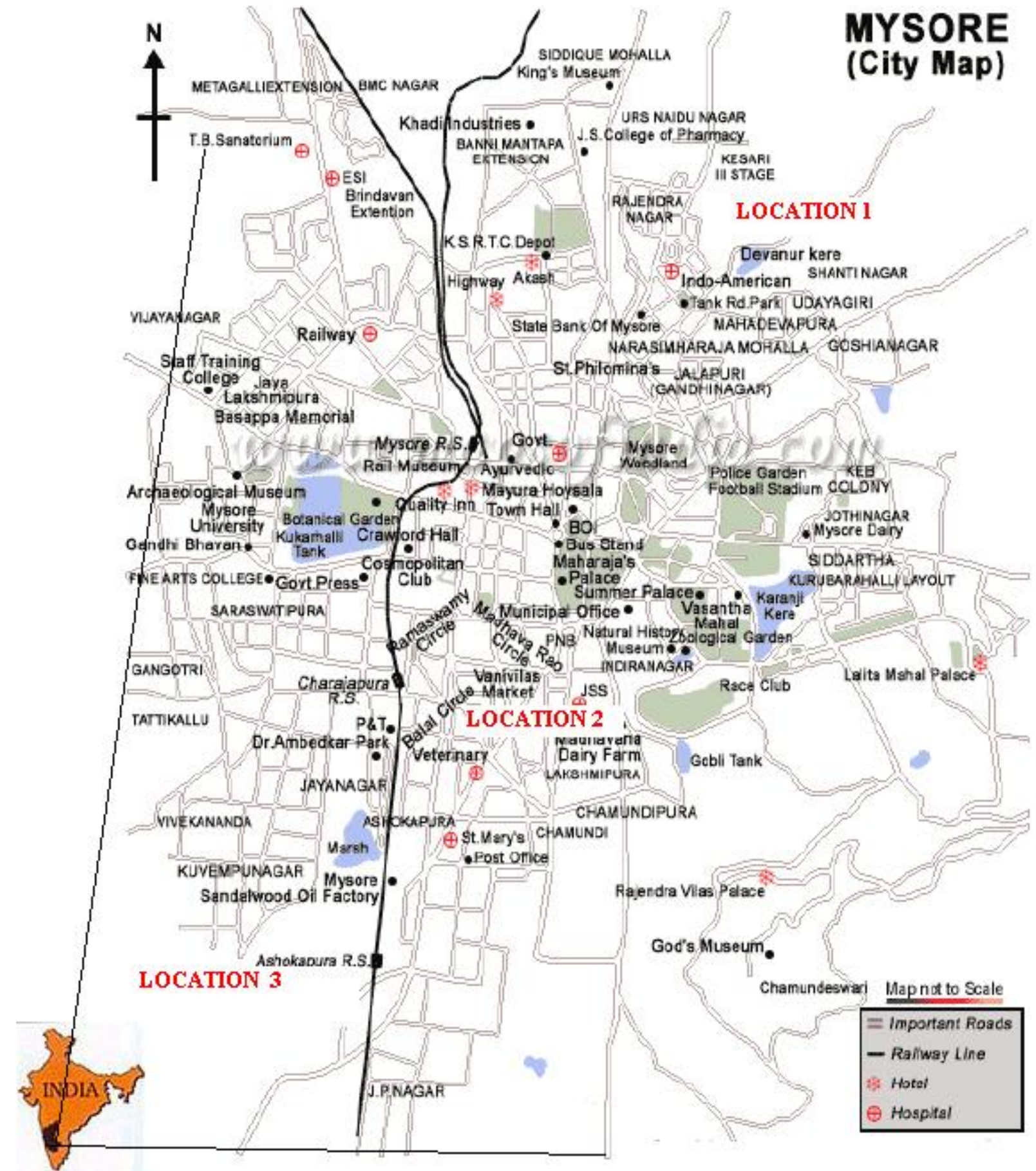

Figure 2. Drainage districts and wastewater treatment plants (Sample locations). 
Table 1. Physico-chemical characteristics of UWW during 2008.

\begin{tabular}{|c|c|c|c|c|c|c|c|c|c|c|c|c|c|c|c|c|c|c|c|}
\hline \multirow{3}{*}{ Sl.No } & \multirow{3}{*}{ Parameters } & \multicolumn{6}{|c|}{ Pre monsoon } & \multicolumn{6}{|c|}{ Monsoon } & \multicolumn{6}{|c|}{ Post monsoon } \\
\hline & & \multicolumn{2}{|c|}{ L1 } & \multicolumn{2}{|c|}{$\mathrm{L} 2$} & \multicolumn{2}{|c|}{ L3 } & \multicolumn{2}{|c|}{ L1 } & \multicolumn{2}{|c|}{ L2 } & \multicolumn{2}{|c|}{ L3 } & \multicolumn{2}{|c|}{ L1 } & \multicolumn{2}{|c|}{$\mathrm{L} 2$} & \multicolumn{2}{|c|}{ L3 } \\
\hline & & Raw & Treated & Raw & Treated & Raw & Treated & Raw & Treated & Raw & Treated & Raw & Treated & Raw & Treated & Raw & Treated & Raw & Treated \\
\hline 1 & $\mathrm{pH}$ & 7.31 & 8.21 & 7.96 & 8.14 & 7.41 & 8.87 & 7.02 & 7.81 & 6.63 & 8.51 & 6.85 & 8.58 & 7.45 & 9.11 & 6.85 & 7.46 & 7.05 & 8.84 \\
\hline 3 & COD (mg/l) & 235.0 & 163.0 & 295.0 & 52.0 & 139.0 & 36.0 & 159.0 & 105.0 & 175.0 & 89.0 & 140.0 & 132.0 & 445.0 & 75.0 & 488 & 83 & 494 & 106.0 \\
\hline 4 & BOD (mg/l) & 125.0 & 45.0 & 141.0 & 15.0 & 15.0 & 9.0 & 12.0 & 7.0 & 17.0 & 6.0 & 10.0 & 5.0 & 300.0 & 18.0 & 370 & 45 & 260 & 10 \\
\hline 5 & TDS (mg/l) & 780 & 600 & 600 & 520 & 680 & 580 & 600 & 530 & 580 & 500 & 540 & 860 & 720 & 620 & 780 & 680 & 800 & 980 \\
\hline 6 & $\mathrm{SS}$ (mg/l) & 100 & 20 & 160 & 20 & 40 & 20 & 140 & 40 & 100 & 60 & 80 & 40 & 360 & 60 & 200 & 20 & 140 & 20 \\
\hline 7 & SAR & 4.6 & 4.76 & 3.98 & 4.52 & 4.3 & 4.54 & 1.65 & 1.84 & 1.22 & 1.24 & 1.08 & 6.2 & 1.72 & 1.95 & 1.99 & 1.89 & 1.87 & 3.69 \\
\hline 8 & $\begin{array}{l}\text { Nitrate-N } \\
(\mathrm{mg} / \mathrm{l})\end{array}$ & 0.04 & 0.3 & 0.09 & 0.28 & 0.15 & 0.23 & 0.28 & 1.12 & 0.2 & 0.61 & 0.186 & 0.257 & 0.4 & 0.17 & 0.16 & 0.07 & 0.11 & 0.32 \\
\hline 9 & $\begin{array}{c}\text { Phosphate } \\
\text { (mg/l) }\end{array}$ & 26.4 & 15.45 & 13.41 & 19.90 & 18.37 & 2.33 & 10.32 & 0.62 & 7.7 & 1.69 & 11.08 & 0.38 & 17.9 & 3.52 & 12.36 & 16.39 & 12.33 & 0.4 \\
\hline 10 & $\begin{array}{l}\text { Potassium } \\
(\mathrm{mg} / \mathrm{l})\end{array}$ & 46 & 42 & 44 & 40 & 40 & 41 & 13 & 18.6 & 7.1 & 8.3 & 5.1 & 3 & 31.8 & 16.8 & 16.8 & 17.6 & 18.8 & 102 \\
\hline
\end{tabular}

Table 2. Heavy metal concentration of UWW in different seasons of 2008 in ppm.

\begin{tabular}{|c|c|c|c|c|c|c|c|c|c|c|c|c|c|c|c|c|c|c|c|}
\hline \multirow{3}{*}{ Sl.No } & \multirow{3}{*}{$\begin{array}{c}\text { Heavy- } \\
\text { metal }\end{array}$} & \multicolumn{6}{|c|}{ Premonsoon } & \multicolumn{6}{|c|}{ Monsoon } & \multicolumn{6}{|c|}{ Post monsoon } \\
\hline & & \multicolumn{2}{|c|}{ L1 } & \multicolumn{2}{|c|}{ L2 } & \multicolumn{2}{|c|}{ L3 } & \multicolumn{2}{|r|}{ L1 } & \multicolumn{2}{|r|}{ L2 } & \multicolumn{2}{|r|}{ L3 } & \multicolumn{2}{|r|}{ L1 } & \multicolumn{2}{|r|}{ L2 } & \multicolumn{2}{|r|}{ L3 } \\
\hline & & Raw & Treated & Raw & Treated & Raw & Treated & Raw & Treated & Raw & Treated & Raw & Treated & Raw & Treated & Raw & Treated & Raw & Treated \\
\hline 1 & $\mathrm{Cd}$ & 0.19 & 0.19 & 0.18 & 0.18 & 0.19 & 0.19 & 0.20 & 0.20 & 0.20 & 0.20 & 0.20 & 0.20 & 0.19 & 0.19 & 0.20 & 0.19 & 0.19 & 0.19 \\
\hline 3 & $\mathrm{Cu}$ & 0.08 & 0.06 & 0.10 & 0.06 & 0.06 & 0.05 & 0.05 & 0.04 & 0.11 & 0.05 & 0.05 & 0.03 & 0.15 & 0.03 & 1.93 & 0.03 & 0.08 & 0.02 \\
\hline 4 & $\mathrm{Fe}$ & 0.89 & 0.48 & 1.51 & 0.63 & 1.68 & 0.77 & 2.04 & 0.80 & 1.92 & 0.62 & 2.20 & 1.94 & 6.38 & 1.00 & 5.66 & 0.94 & 7.97 & 3.14 \\
\hline 5 & $\mathrm{Ni}$ & 0.58 & 0.53 & 0.53 & 0.42 & 0.56 & 0.23 & 0.31 & 0.33 & 0.30 & 0.31 & 0.38 & 0.26 & 0.76 & 0.49 & 0.68 & 0.58 & 0.52 & 0.40 \\
\hline 6 & $\mathrm{~Pb}$ & BDL & BDL & BDL & BDL & BDL & BDL & BDL & BDL & BDL & BDL & BDL & BDL & BDL & BDL & BDL & BDL & BDL & BDL \\
\hline 7 & $\mathrm{Zn}$ & 0.17 & 0.14 & 0.27 & 0.06 & 0.09 & 0.07 & 0.09 & 0.19 & 0.18 & 0.14 & 0.09 & 0.05 & 1.34 & 0.24 & 0.71 & 0.18 & 0.36 & 0.23 \\
\hline
\end{tabular}

\subsection{Biochemical Oxygen Demand (BOD)}

BOD is the most widely used parameter to measure water quality and to design the waste water treatment plants. The determination of BOD involves the measurement of the dissolved oxygen (DO) used by microorganisms in the biochemical oxidation of organic matter, and is a measure of organic pollution.

BOD in the untreated UWW is high as of the organic content in the city wastewater is usually high. In the present study, BOD of untreated UWW ranged from 10 $\mathrm{mg} / \mathrm{l}$ to $370 \mathrm{mg} / \mathrm{l}$ during dry season and the BOD of treated UWW show a range from $5.0 \mathrm{mg} / \mathrm{l}$ during mon- soon to $45 \mathrm{mg} / \mathrm{l}$ during dry season. During dry seasons, the BOD of untreated UWW exceeds the CPCB Standards. After biological treatment in the Lagoons, BOD is reduced and is very much within the CPCB standards. Continuous irrigation and high organic matter contents may clog soil pores; however, this usually does not occur unless BOD levels exceed $500 \mathrm{mg} / \mathrm{l}$ [7]. The BOD of treated and untreated UWW is shown in Figure 4.

\subsection{Chemical Oxygen Demand (COD)}

The COD test is used to measure the oxygen equivalent of the organic material in wastewater that can be oxidized 


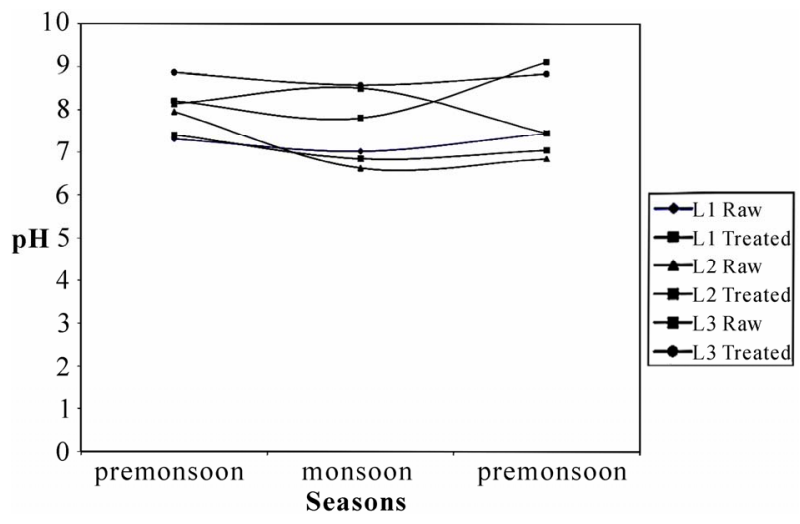

Figure 3. pH of treated and untreated UWW.

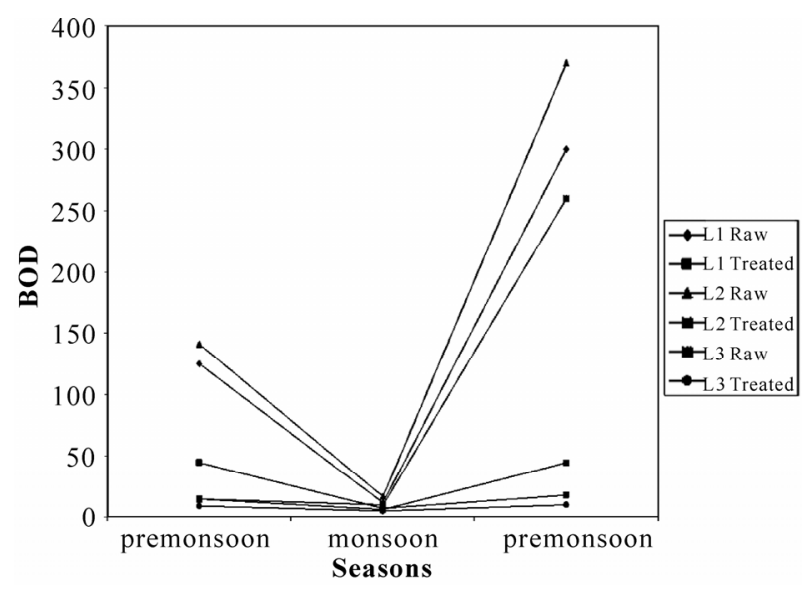

Figure 4. BOD of treated and untreated UWW.

chemically using dichromate in acid solution. COD in UWW is due to the presence of organic matter present in sewage mainly in the form of food waste.

In the present study COD of untreated UWW ranged from $139 \mathrm{mg} / \mathrm{l}$ during pre monsoon to $494 \mathrm{mg} / \mathrm{l}$ during post monsoon. Also treated UWW show a range from 36 $\mathrm{mg} / \mathrm{l}$ to $163 \mathrm{mg} / \mathrm{l}$ during pre monsoon season. COD of untreated and treated UWW during monsoon is well within the CPCB inland surface water standards. However the COD of untreated UWW at location No. 2 during pre monsoon and at all the locations during post monsoon seasons are exceeding the standards. However after the biological treatment in the lagoons, the COD of the treated UWW at all treatment plants is very much reduced and well within the standards. The primary treatment process has reduced the BOD and COD concentrations. Chandrasekaran et al. [8] also reports the same findings. The COD of treated and untreated UWW is shown in Figure 5.

\subsection{Electrical Conductivity (EC) and Total Dissolved Solids (TDS)}

Electrical conductivity (EC) is a measure of the ions present in water, the conductivity increases with the increase of ions. It is also effectively a surrogate for total dissolved solids (TDS) and is important for irrigation because it is a measure of the salinity of the water. The conductivity test does not identify the dissolved salts or the effects they may have on crops or soil, but it does indicate fairly reliably the degree with which a salinity problem is likely to occur. Salinity restricts the availability of water to plants by lowering the total water potential in the soil. Salinity also has an impact on crop physiology and yield with visible injury occurring at high salinity levels. Usually crop yield is independent of salt concentration when salinity is below some threshold level then yield gradually decreases to zero as the salt concentration increases to the level which cannot be tolerated by a given crop. Rice is a crop which is moderately sensitive to salt.

In the present study EC of untreated UWW show a range from $0.96 \mathrm{dS} / \mathrm{m}$ during monsoon to $1.31 \mathrm{dS} / \mathrm{m}$ during pre monsoon. EC of treated UWW showed a range from $0.74 \mathrm{dS} / \mathrm{m}$ during monsoon to $1.51 \mathrm{dS} / \mathrm{m}$ during post monsoon EC values of untreated and treated UWW at all the three locations lie within the slight to moderate range of the FAO irrigation water quality standards.

TDS of untreated UWW in the present study show a range of $540 \mathrm{mg} / \mathrm{l}$ during monsoon $800 \mathrm{mg} / \mathrm{l}$ during post monsoon season. Also the treated UWW showed a range from $520 \mathrm{mg} / \mathrm{l}$ during pre monsoon to $980 \mathrm{mg} / \mathrm{l}$ during post monsoon. TDS of untreated and treated UWW at all the three locations lie within slight to moderate range of the FAO irrigation water quality standards. The primary treatment brought certain reduction in EC and TDS. Muthukumaran et al. [9] also reports that primary treatment reduces the EC and TDS concentrations. However it is exceptional at the treatment plant at location No. 3, where there is increase in EC and TDS in the treated UWW, which is understandable because suspended materials along with the salts are not settled completely. Excessive total salt concentration or excessive levels of

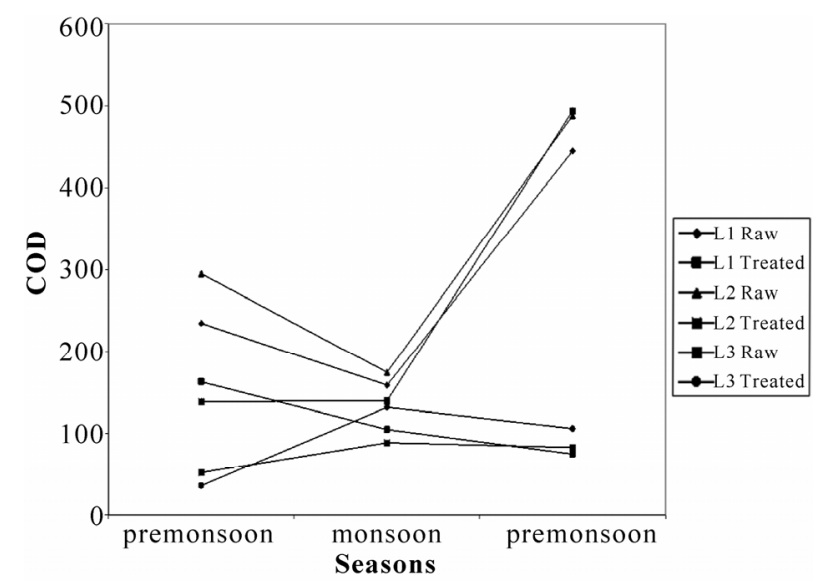

Figure 5. COD of treated and untreated UWW. 
some potentially toxic elements can have detrimental effects on plant health and/or soil conditions. The EC and TDS of treated and untreated UWW is shown in Figures 6 and 7 respectively.

\subsection{Suspended Solids (SS)}

The results of the present study show that in the untreated UWW, SS ranged from 40mg/l during premonsoon season to $360 \mathrm{mg} / \mathrm{l}$ highest during post monsoon season. SS in the treated UUW ranged from $20 \mathrm{mg} / \mathrm{l}$ during dry season to $60 \mathrm{mg} / \mathrm{l}$ during monsoon and post monsoon season. The primary treatment has considerably reduced the SS concentration. However the concentration of SS exceed the general standard of $20 \mathrm{mg} / \mathrm{l}$ stipulated by the State Pollution Control Board for discharge of effluent on land for irrigation.

\subsection{Sodium Absorption Ratio (SAR)}

SAR indicates the effect of relative cation concentration on Sodium accumulation in the soil. Present study shows SAR in untreated UWW from 1.08 to 4.76 during monsoon and premonsoon seasons respectively. Also in treated UWW, SAR ranged from 1.24 to 6.2. SAR in the untreated and treated waste water lies within the slight to moderate range of the FAO irrigation water quality standards. The SAR in the untreated and treated UWW is high during premonsoon season when compared to other seasons. There is no significant reduction in SAR in the treated UWW and SAR of the treated UWW at location No.3 is highest because of high concentration of sodium and incomplete treatment process. Continued use of water having SAR can lead to a breakdown in the physical structure of the soil. Any increase in the SAR in irrigation water increases the SAR of the soil solution, which ultimately increases the exchangeable sodium by the soil, leading to the loss of permeability. The SAR of untreated and treated UWW is shown in Figure 8.

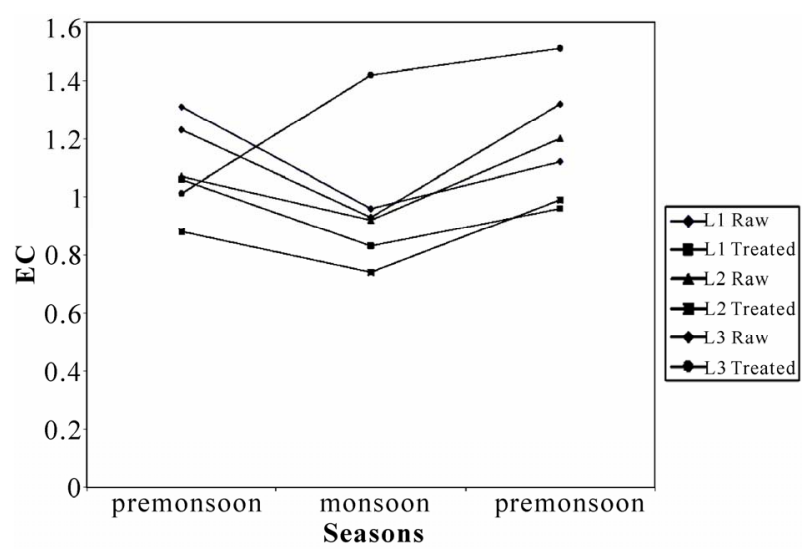

Figure 6. EC of treated and untreated UWW.

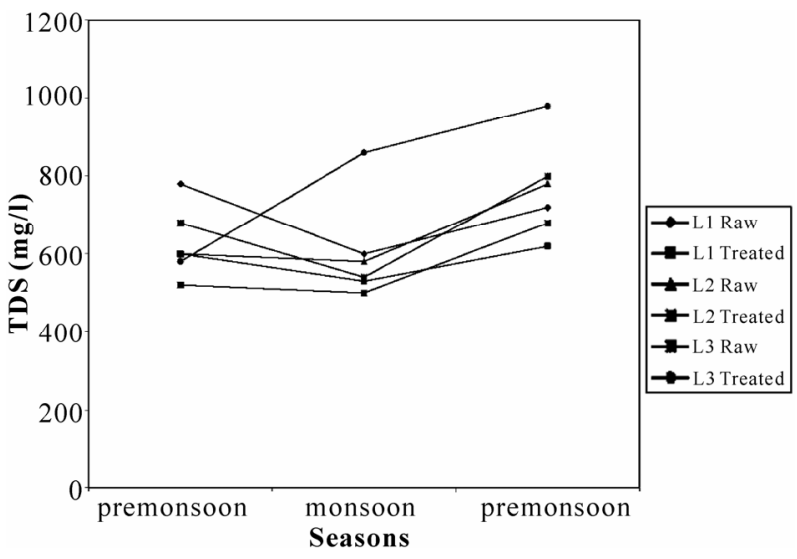

Figure 7. TDS of treated and untreated UWW.

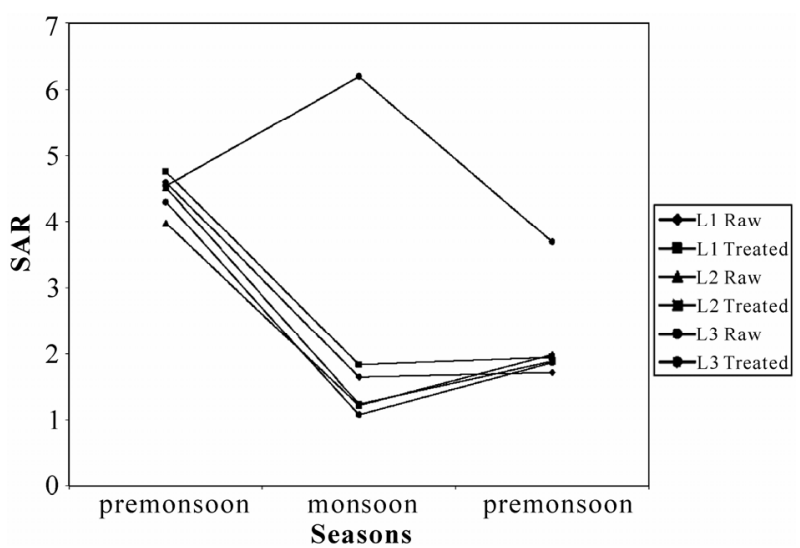

Figure 8. Sodium Absorption Ratio of treated and untreated UWW.

\subsection{Nitrate $\left(\mathrm{NO}_{3}-\mathrm{N}\right)$}

$\mathrm{NO}_{3}-\mathrm{N}$ is a necessary primary macronutrient for plants that stimulates plant growth and is usually added as a fertilizer but can also be found in wastewater as nitrate, ammonia, organic nitrogen or nitrite [10]. The most important factor for plants is the total amount of nitrogen (N) regardless of whether it is in the form of nitrate-nitrogen $\left(\mathrm{NO}_{3}-\mathrm{N}\right)$, ammonium nitrogen $\left(\mathrm{NH}_{4}-\mathrm{N}\right)$ or organic-nitrogen (Org-N) but by reporting in the form of total nitrogen comparisons can be made [11]. The concentration of nitrogen required varies according to the crop with more sensitive crops being affected by nitrogen concentrations above $5 \mathrm{mg} / \mathrm{l}$, whilst most other crops are relatively unaffected until nitrogen exceeds $30 \mathrm{mg} / \mathrm{l}$.

$\mathrm{NO}_{3}-\mathrm{N}$ results of untreated UWW show a range from $0.04 \mathrm{mg} / \mathrm{l}$ to $0.4 \mathrm{mg} / \mathrm{l}$ during dry seasons. In treated UWW, $\mathrm{NO}_{3}-\mathrm{N}$ ranged from $0.07 \mathrm{mg} / \mathrm{l}$ to $0.32 \mathrm{mg} / \mathrm{l}$ during dry season. The $\mathrm{NO}_{3}-\mathrm{N}$ of untreated UWW ranged from minimum of $0.04 \mathrm{mg} / \mathrm{l}$ during premonsoon to a maximum of $0.4 \mathrm{mg} / \mathrm{l}$ during post monsoon at location No. 1. The $\mathrm{NO}_{3}-\mathrm{N}$ of treated UWW ranged from a minimum of $0.07 \mathrm{mg} / \mathrm{l}$ during post monsoon to a maxi- 
mum of $0.61 \mathrm{mg} / \mathrm{l}$ during monsoon at treatment plant at location No. 2. Due to incomplete treatment process and the waste water becoming more enriched in nutrient, the concentration of the $\mathrm{NO}_{3}-\mathrm{N}$ is increased in the treated UWW. However the values lie within the safe range of restriction on use of FAO irrigation water quality standards.

\subsection{Phosphate $\left(\mathrm{PO}_{4}\right)$}

Phosphorus is also a primary macronutrient that is essential to the growth of plants and other biological organisms but quantities can be excessive and if the concentrations in water are too high noxious algal blooms can occur. Phosphates are classified as orthophosphates, polyphosphates and organic phosphates. Municipal waste waters may contain between 4 and $16 \mathrm{mg} / \mathrm{l}$ of phosphorus [5].

Wastewater with 6-20 mg/l phosphorous increases the productivity of the crops and when the concentration exceeds $20 \mathrm{mg} / \mathrm{l}$ the availability of copper, iron and zinc is reduced in alkaline soils [7]. The highest value of dissolved phosphate reported in the present study is 26.4 $\mathrm{mg} / \mathrm{l}$ in the untreated UWW at location No.1 during pre monsoon season. The primary treatment brought some reduction in phosphate concentration, but it is exceptional in treatment plant at location No. 2 during premonsoon and post monsoon seasons.

Wastewater normally contains low amounts of phosphorous, so its use for irrigation is beneficial and does not negatively impact the environment. This is the case even when wastewater effluents with high concentration of phosphorous are applied over long periods of time although, because phosphorous builds up at the soil surface, it can affect surface waters through soil erosion and runoff [7]. The concentration of $\mathrm{PO}_{4}^{3-}$ of untreated and treated UWW is shown in Figure 9.

\subsection{Potassium}

Potassium is not an integral part of any major plant component but it does play a key role in a vast array of physiological processes vital to plant growth, from protein synthesis to maintenance of plant water balance. Potassium is a macro-nutrient that is present in high concentrations in soils but is not bio-available since it is bound to other compounds. Generally, wastewater contains low potassium concentrations insufficient to cover the plant's theoretical demand, and use of wastewater in agriculture does not normally cause negative environmental impacts [12].

Potassium may originate from human faeces and urine disposal, as human faeces has on average $1.6 \%$ and urine has $3.7 \%$ (dry weight) potassium. The concentration of potassium of untreated UWW was recorded highest of 46 mg/l during premonsoon season to a minimum of 5.1 during monsoon. The treated UWW show a maximum of $102 \mathrm{mg} / \mathrm{l}$ during post monsoon season and a minimum of $3 \mathrm{mg} / \mathrm{l}$ during monsoon at the treatment plant at location No. 3. The primary treatment has not significantly reduced the concentration of potassium at plant No. 1 and 2 during monsoon and post monsoon season which may be attributed to the incomplete treatment and may be due to dumping of the municipal solid waste at the outlet of treatment plant at location No. 2. The concentration of potassium of untreated and treated UWW is shown in Figure 10.

\subsection{Heavy Metals Concentration}

Trace quantities of many metals can be found in wastewaters, particularly industrial waste but also arising from domestic waste, for example from household cleaning products. Many of these metals are necessary for growth of biological life but only in trace concentrations; if the required concentrations are exceeded they can become toxic and thus interfere with the potential beneficial uses

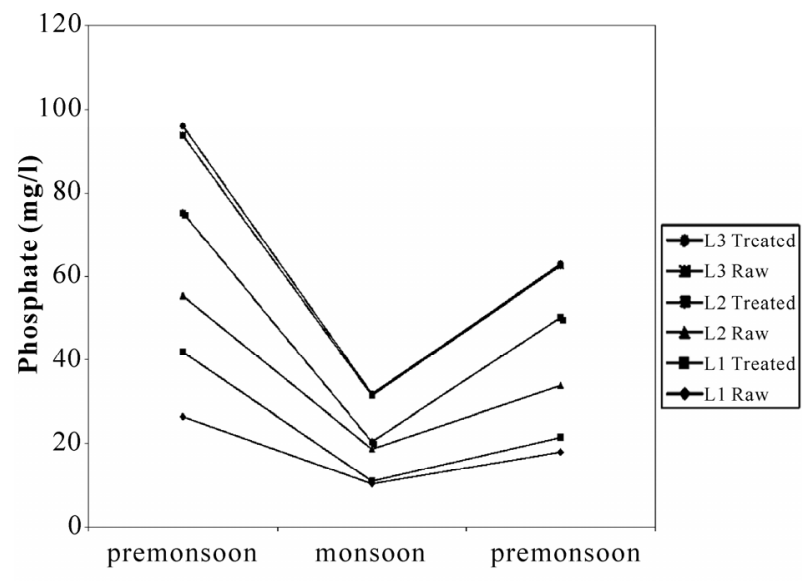

Figure 9. Phosphate of treated and untreated UWW.

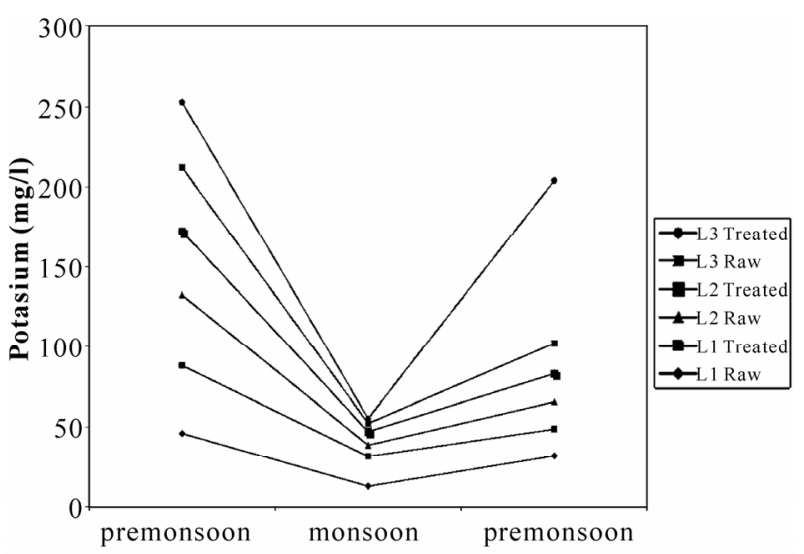

Figure 10. Potassium of treated and untreated UWW. 
of wastewater.

The untreated and treated UWW were analyzed for identification of metals which were either beneficial for plant growth, or likely to cause damage to crops or impact on human health. Heavy metals like Nickel, Copper, Cadmium, Chromium, Iron, Zinc and Lead were analyzed using Inductively Coupled Plasma atomic emission Spectroscopy techniques (ICP-AES). Among these Iron and Copper can help plant growth and development, but other heavy metals directly or indirectly affect the plant growth and development to various degrees and above different threshold levels. The results are shown in Table 2.

The results of heavy metal concentration of UWW showed that lead was not detected in any of the samples. Concentration of Iron in untreated UWW at all locations and during all seasons is on the higher side when compared in the treated UWW. Comparatively iron concentration in untreated and treated UWW is highest during post monsoon season. This might be due to the combine sewer system receiving arising runoff during the wet season which contains Iron, one of the most abundant elements in the environment [13] and also it may be due to corrosion of water supplying pipes.

Concentration of Copper, nickel, and Zinc in untreated UWW at all locations and at all seasons is more than in treated UWW. Whereas, the concentration of Cadmium and chromium in untreated and treated UWW does not significantly show the difference. Similar reports are recorded by [14]. Among the heavy metals, the concentration of Chromium, Cadmium, Nickel, and Iron (in post monsoon season) are exceeding the FAO standards. Also it can be implied that biological treatment process which mainly established for the removal of organic matters and nutrients can additionally remove metal contents from wastewater

\section{Conclusions}

The parameters like BOD and COD of untreated UWW exceed the CPCB permissible limit for disposing the UWW on land for irrigation, but EC, TDS and SAR are within the average range of the FAO irrigation water quality standards. The undesirable effects include that the entire quantity of urban waste water generated at Mysore city limits is not collected for treatment and as such the untreated waste water finds its way into water bodies and also to the agricultural land thus resulting in contamination of water bodies and soil pollution.

Seasonal variations act upon a number of factors that influence the toxicity of UWW and its effects in the receiving environment. The factors affected include dissolved oxygen concentrations in receiving waters, temperature of the wastewater and the receiving environment, water levels and assimilative capacity, the types of contaminants that accumulate on urban surfaces and the efficiency of UWW treatment plants.

Nutrients are clearly present in the wastewater, and especially phosphorus is high in content. The presence of nutrients can be beneficial for agricultural use, but the quantities need to be known before they are applied. In order to bring down the deterioration of water bodies and soil condition, it is recommended Best Management Practices (BMPs) by connecting all the missing links to the waste water treatment plants and upgradation and continuous operation of the existing treatment plants. Solid waste has to be prevented from being dumped into the canals and near the waste water treatment plants by ensuring regular collections, increasing composting and recycling in collaboration with the existing solid waste management programs in the area.

\section{Acknowledgements}

Authors are thankful to University Grants Commission, New delhi, for awarding the Major research Project and also one of the author Mrs.Shakunthala Bai is grateful to KSPCB for permitting to carry out the research work.

\section{References}

[1] W. van der Hoek, et al., “A Frame Work for a Global Assessment of the Extent of Wastewater Irrigation: The Need for a Common Wastewater Typology, ” International Water Management Institute (IWMI), Bierstalpad, 2004.

[2] A. Bradford, R. Brook and C. S. Hunshal, "Wastewater Irrigation in Hubli-Dharwad, India: Implications for health and livelihoods," Environment \& Urbanization, Vol. 15, No. 2, October 2003, pp. 157-170.

[3] F. Marshall, R. Sharma, et al., "Waste Water Irrigation and Heavy Metal Contamination in Peri-Urban India," Geophysical Research Abstracts, Vol. 8, No. 09058, 2006.

[4] American Public Health Association, "Standard Methods for the Examination of Water and Waste Water," American Public Health Association, Water Environment Foundation and American Water Works Association, Washington, D.C., 1998.

[5] T. Asano, F. L. Burto, H. L. Leveren, R. Suchihashi and G. Tchobanoglous, "Wastewater Engineering Treatment and Reuse,” 4th Edition, McGraw Hill, New York, 2003.

[6] T. A. Bauder, G. E. Cardon, R. M. Waskom and J. G. Davis, “Irrigation Water Quality Criteria,” 2004.

[7] World Health Organization, "WHO Guidelines for the Safe Use of Wastewater, Excreta and Greywater: Volume II Wastewater use in Agriculture,” WHO, Geneva, 2006.

[8] Chandrasekaran and Rajkannan, "Nature and Characteristics of Sewage Effluents of Tamil Nadu," The Madras Agricultural Journal, Vol. 90, No. 1-3, 2003, pp. 
124-128.

[9] N. Muthukumaran and Dr. N. K. Ambujam, "Wastewater Treatment and Management in Urban Areas-A Case Study of Tiruchirappalli City, Tamil Nadu, India,” Proceedings of the 3rd International Conference on Environment and Health, Chennai, 15-17 December 2003, pp. 284-289.

[10] M. B. Pescod, "Wastewater Treatment and Use in Agriculture," Food and Agriculture Organization (FAO) Irrigation and Drainage Paper, 1992, p. 73.

[11] R. S. Ayres and D. W. Westcot, "Water Quality for Agriculture," FAO Irrigation and Drainage Paper, No. 29, Rev. 1, Food and Agriculture Organization, Rome, 1994, p. 59.

[12] R. Mikkelsen and J. Camberato, "Potassium, Sulfur,
Lime and Micronutrient Fertilizers,” In: J. Rechcigl, Ed., Soil Amendments and Environment Quality, Lewis Publishing, Boca Raton, 1995, pp. 109-137.

[13] J. Lester, "Heavy Metals in Wastewater and Sludge Treatment Process, ” CRC Press, Inc., Boca Raton, 1987, pp. 1-40.

[14] P. Chanpiwat1, K.-W. Kim and S. Sthiannopkao, "Metal Contents and its Variation in Wastewater and Sewage Sludge: A Case Study of Bangkok Central Wastewater Treatment Plants," Proceedings of the International Symposia on Geoscience Resources and Environments of Asian Terranes (GREAT 2008), 4th International Geological Correlation Programme (IGCP) 516, and 5th Asia Pacific School of Economics and Government, Bangkok, 24-26 November 2008. 